\title{
Local Government Systems and Decentralization: Evidence from Pakistan's Devolution Plan
}

\author{
Muhammad Shakil Ahmad ${ }^{1,2} \&$ Noraini Bt. Abu Talib ${ }^{1}$
}

\begin{abstract}
The discourse of governance and development practitioners continues to embrace community participation and community empowerment as an elementary means of building local capacity for poverty reduction, development and change at the local level. This article is a review of the decentralization initiatives of local government systems after the announcement of the devolution plan in Pakistan. It evaluates the initiatives' participatory methods to ascertain the extent to which they have improved the process of community development at the local level. This article also measures the impact of community empowerment on the sustainability of community-driven projects implemented under the decentralization initiative through community-based organizations known as Citizen Community Boards (CCBs). Document analysis and literature review methodologies were employed to gain further insight into the decentralization phenomenon in Pakistan. The results describe human development, improvements in community empowerment and the sustainability of local projects; however, the sense of community has yet to be translated into shared benefits for rural communities. The fundamental goal of decentralization seems to be elusive because only power was transferred to the local level, whereas there is little support for community capacity building and community access to resources and the elites still control the electoral process. It is argued that community development initiatives in Pakistan require continuous support from local governments to boost local rural economies. Likewise, community-local government participatory development strategies can lead to strong local ownership and empowerment in rural communities.
\end{abstract}

KEY WORDS: $\quad$ decentralization, community empowerment, citizen community boards, sustainability, community driven development

JEL Classification: H7

${ }^{1}$ Universiti Teknologi Malaysia, Malaysia; ${ }^{2}$ COMSATS Institute of Information Technology, Pakistan

\section{Introduction}

In the past two decades, decentralization initiatives have emerged as an important instrument of local deㅁ velopment policy in developing countries. Through the

Correspondence concerning this article should be addressed to: Muhammad Shakil Ahmad, Faculty of Management and $\mathrm{Hu}$ man Resource Development, Universiti Teknologi Malaysia, 81310, Skudai, Johor, e-mail: onlyshakil@gmail.com decentralization of decision making, governments can achieve diverse goals, including community participation, development of social capital, resource management, sustainable development of community resources and service provision at the local level. Alderman (2002) noted that 'decentralization is sometimes seen as a good in itself, as policy makers defined their policy choices more often on grounds of increased efficiency, greater equity, and higher responsiveness of government to 
citizen'(p. 378). Andersson, Gibson, and Lehoucq (2004) described the perceived benefits of decentralization, such as greater access to decision makers, higher levels of participation in decision making by various social groups and accountability for decision makers.

In Pakistan, community participation in local development is associated with the Devolution Plan, which was adopted in 2000 and implemented in 2001 as a part of decentralization policy after the announcement of the local government system. The argument presented in favor of this devolution plan was that the new local government system would provide a platform for local governance through the development of proactive communities and improved community representation and empowerment. In turn, community involvement would spearhead grass-roots interaction with key stakeholders and lead to better service delivery and development in the area. The system was introduced to safeguard the interests of local communities through their active participation in development and decision-making processes by supporting them through clear administrative responsibilities without political interference. The decentralization initiative was proposed under the assumption that the local community would actively participate in decision-making processes regarding local development and would be able to demand responsiveness and accountability from its leaders. It was also assumed that decentralization would eliminate control by elites and the central government over local development actors; in reality, the results are mixed (Agrawal \& Gupta, 2005; Anjum, 2001; Bardhan, 2002; Patrick \& Scott, 2011; Paul, 2010; Rondinelli, 2006).

Importantly, decentralization initiatives in Pakistan have enhanced community participation at the local government level; resource mobilization, improvement in local service delivery and especially the introduction of community-based groups called Citizen Community Boards (CCBs) ${ }^{1}$ have helped marginalized communities to become empowered through selfdevelopment initiatives. The working mechanisms of CCBs are similar to those of Community Driven Development (CDD) approaches. As in CCD approaches, community contribution is mandatory. In addition, communities share $20 \%$ of CCB project costs to ensure local participation in and the need for a particular project. CDD is considered to be a successful mecha- nism because it involves the local communities, especially the poor, in identifying and serving their unmet needs, thus generating local ownership and empowerment in communities (Dongier et al., 2003; George \& Costel, 2011; Mansuri \& Rao, 2003). However, in the case of Pakistan, CCBs face problems of elite control and political interference in obtaining funds as well as in registration.

This article thus examines the existing participatory rural development framework (local government ordinance system, 2001) in Pakistan in order to determine the extent to which decentralization mechanisms support the socioeconomic and political prospects of community development in rural territories. The following section elaborates the theoretical framework of community empowerment and rural development before analyzing the structural changes made to local governments after decentralization in Pakistan. This section is followed by an evaluation of current community empowerment mechanisms, including elite control, social issues, accountability and the contribution of CCBs to rural development.

\section{Framework for community empowerment and rural development}

Community empowerment strategies are closely linked with social inclusion. Empowerment occurs on an individual level, whereas social inclusion occurs at the system or institutional level. Social inclusion is an important mechanism for overcoming institutional barriers (for example, lack of information, ineffective services, lack of access to community programs and lack of community-focused services) and enhancing policy structures to help the poor and other marginalized groups to access assets and developmental opportunities. International development agencies are currently focusing on bottom-up participatory community-based development strategies, shifting their emphasis from the central government to the community development context. Empowerment is defined as the power to accomplish something individually or collectively, and can it be used to exert pressure on institutions and policy makers to reform policies that affect citizens' quality of life. Empowerment enables the poor to overcome the barriers that prevent them from accessing new livelihood opportunities (Saegaert, 2006). To accommodate mar- 
ginalized communities, decentralized approaches are helpful in improving service delivery at the local level (Roche, 2010; Salmon, 2007). It is assumed that such participatory and community-based initiatives will help citizens to improve their capabilities for collective action, which can result in significant development outcomes, such as access to basic necessities, improved quality of life and decline in social exclusion and inequality (Gutberlet, 2009).

\section{Community Empowerment}

Empowerment has been defined in various ways by different disciplines. The literature states that community involvement in developmental processes is helpful in exerting social influence over developmental actors and that it serves to increase the capacity of local communities (Corbett \& Keller, 2004; Hjorth, 2003; Buss, Marcela, \& Redburn, 2011; Wallerstein, 2006). Speer et al. (2001) described empowerment as an ongoing international process centered on local communities and that involves collaborative and mutual efforts to increase community control over resources and information. Improvements in community capacity are not only helpful in engaging communities in the development process but are also a way for communities to influence the decisions made by local institutions that affect their lives. At the individual level, empowerment entails three components: cooperation between individuals in improving capacities and skills, individual management of local resources and individual participation in decision making processes (Schulz, Israel, \& Zimmerman, 1995; Zimmerman, 2000).

Empowerment is not a static, one-time experience but rather an ongoing and continuous process. Improvements in community capacity help communities to manage local resources in a self-sufficient manner. Laverack (2001) reported three elements of empowerment: community participation, local organizational capacity and accountability. He further described a link between empowerment, participation and leadership. Within the social policy context, empowerment is a means to provide citizens with opportunities to participate, which in turn enables them to act and ultimately to improve their quality of life (Sidorenko, 2006). The outcomes of empowerment initiatives can be manipulated upon the completion of projects, and they can influence the economic, political and insti- tutional decisions of policy makers. Empowerment is a way of resisting factors that directly or indirectly negatively impact community lives. Similarly, Alsop and Heinsohn (2005) stated that empowerment is a process that enhances the capacities of individuals or groups so that they can make their own choices, transforming these choices into favorable actions and outcomes. Capacity building is the fundamental requirement for effective decision making. The degree of empowerment varies according to the situation and is dependent on the availability, use and implementation of decisions. Furthermore, community empowerment is not an individual act but requires collective community action and equal engagement from all community members. As illustrated by Narayan and Petesch (2002), communities are considered to be empowered if they participate in decision-making processes, have the capacity and resources to fulfill unmet needs and have access to current and comprehensible information. The following section highlights each of these components and its contribution to rural development.

\section{Linking Community Empowerment and Rural Development}

Community empowerment has become increasingly important and is considered to be a starting point for local development. Empowerment is defined by Narayan and Petesch (2002) as 'the process of enhancing the real possibility that an individual or a group can make and express choices, and transform their choices into desired actions and outcomes'. Community participation, as elaborated by Fox and Meyer (1995), is important in orienting government programs towards common needs, building public support and fostering a sense of ownership or community within society. Andrews and de Vries (2007) indicated that empowered communities need both the opportunity and the capability to make meaningful decisions. Capabilities are essential to address, define, assess and act on community-related issues (Laverack, 2006). Information is considered to be a source of power for marginalized communities (Power, Khatun, \& Debeljak, 2011). Informed citizens are better equipped to take advantage of available opportunities, access services, exercise their rights and hold local and national institutional actors accountable. Khwaja (2004) illustrated two perspectives related to the construct of 


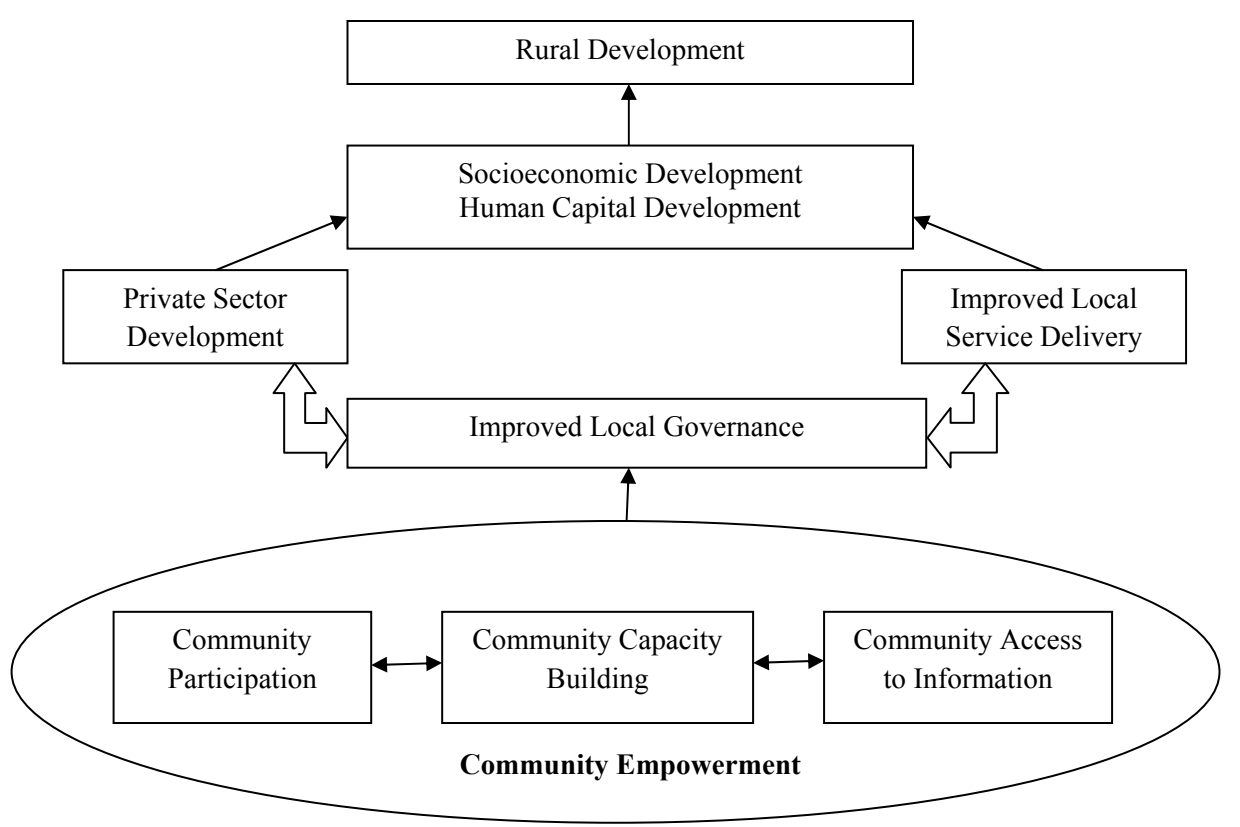

Figure 1. Framework of community empowerment linkage with rural development

access to information: "provision of information" and "access to information". When local communities are empowered, they are both able to provide information about their own priorities and to collect information from local institutions or outside agencies that may, in turn, enhance the local capacity of communities to make good decisions that result in local improvements. Both the provision of and access to information improve local conditions and increase the welfare of local empowered communities. Improved local governance is related to the way that decisions are made and implemented by or on behalf of local communities. The allocation of authority to local governments improves the provision of public services to communities and encourages them to become entrepreneurs through self-development initiatives. Well-informed communities that achieve capacity improvements through local government support can efficiently contribute to private sector development (Power, Khatun, \& Debeljak, 2011). Developing the private sector in rural areas provides the economic foundation for agriculture and agribusiness.
Such fundamental developments not only include training-based enterprises but also myriad forms of informal sector production and commerce that are common to poor communities.

The impact of decentralized local development resulting from the alignment of community empowerment, local governance, improved service delivery and private sector development arrangements includes community welfare and the accumulation of uman, social and economic capital (Ahmad \& Talib, 2010a; Bowles \& Gintis, 2002; Duncana \& Goodwina, 2008; Kakumba, 2010; Rondinelli, 1980). Human social capital is accumulated through the development of skills and capacities to take collective action and the development of human capital through the improvement of individual health and education in local communities. Meanwhile, increasing the capacity of individuals and firms for investment paves the way for increased economic capital (Campbell, Hughes, Hewstone, \& Cairns, 2010; Dale \& Newman, 2010).

This framework linking community empowerment with rural development identifies elements of the self- 


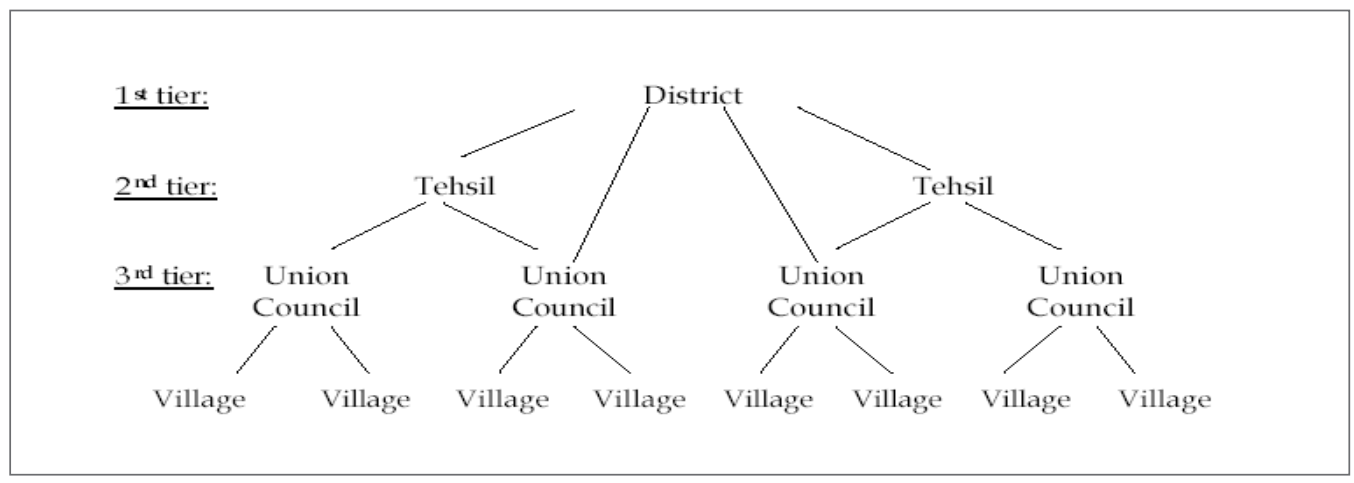

Figure 2. Three tiers of local government

reinforcing systems through which empowered local actors contribute to improved local governance systems, private sector development and service delivery. The alignment of these concepts leads to the accumulation of and investment in mutually beneficial forms of human, social, and economic capital. Increases in human, social and economic capital then stimulate poverty reduction mechanisms, enhance quality of life, and promote rural development. This trend is presented in Figure 1, which demonstrates the linkage of community empowerment with rural development. It is important to note that community empowerment is the fundamental foundation that must be established before benefits for poverty reduction and rural development can be realized.

With its agricultural economy, Pakistan requires high productivity, greater returns on production and investment, a low unemployment rate and economic growth (Cheema \& Mohmand, 2007; Kurosaki, 2005). Unfortunately, popular participation in Pakistan is largely focused on political representation rather than integrated methods to enhance the agricultural capabilities of local communities. To promote good governance and participatory development, many Asian nations have undertaken substantive initiatives through decentralization, but most of them are facing difficulties in translating reform initiatives into specific operations to fulfill the requirements of proactive citizens, mobilize resources and increase budgets (Agrawal \& Gupta, 2005; Fraser, 2005; Michels \& De Graaf, 2010). The major hurdles, according to Paul (2010), are the central government's lack of interest in local bodies, accountability and organizational support for decen- tralization reforms and capacity as well as its political interference. As in many African countries, events unfolding in Pakistan point to the 'recentralization' of decentralization (Ahmad \& Talib, 2010b; Cheema \& Mohmand, 2007; Hankla \& Downs, 2010; Kurosaki, 2006; Paul, 2010), a situation that hinders effective community participation, community empowerment and rural development.

Before explaining the political hierarchy and participatory avenues and how they have affected the rural development process in Pakistan, it is essential to clarify local government organizations and classifications in Pakistan under the decentralization reforms.

\section{Decentralized Local Government Structure in Pakistan}

Before decentralization, the central bureaucracy also governed at the provincial and district levels. These controlling authorities lacked horizontal integration and adequate functional coordination among different departments. This structural and systemic disconnect led to inefficiency and corruption and was the root cause of the crisis of governance at the grass-roots level. Under the new LGS 2000, the local government was divided into three tiers: district, tehsil and union. Each tier has its own line of authority that includes the elected Nazim and Naib Nazim. The district is considered to be the highest level of local governance, and it encompasses larger metropolitan areas and cities. The middle tier of local governance is the tehsil, which is equivalent to the town, whereas the third tier of local government is called the union council and comprises groups of villages (Ahmad \& Talib, 2011; Anjum, 2001; 
Table 1. Decentralized local government structure

\begin{tabular}{ccccc}
\hline Administration & Council & $\begin{array}{c}\text { Status of } \\
\text { administration }\end{array}$ & Elected political head & Administrative head \\
\hline District & District Council & District administration & District Nazim & $\begin{array}{c}\text { District Coordination } \\
\text { Officer (DCO) }\end{array}$ \\
Tehsil & Tehsil Council & $\begin{array}{c}\text { Tehsil Municipal } \\
\text { Administration }\end{array}$ & Tehsil Nazim & $\begin{array}{c}\text { Tehsil Municipal Officer } \\
\text { (TMO) }\end{array}$ \\
Union & Union Council & Union administration & Union Nazim & Union Nazim \\
Village & Union administration & Union Nazim and Naib & Union Nazim \\
\hline
\end{tabular}

Kurosaki, 2006; NRB, 2001; Paul, 2010). Figure 2 provides a brief description of the three tiers of local government.

The first tier of local government is the district. The major responsibilities of the district government are to prepare plans, formulate and execute policies, allocate budgets and monitor legislation at the district level. The district is controlled by the elected District (Zila) Nazim and the head of district administration, known as the District Coordination Officer (DCO), who reports to the District Nazim. The local governance system in Pakistan differs from local government hierarchies in developing countries such as India. In India, the district is further subdivided into four levels: 'Zila Panchayat', 'Panchayat Samiti', 'Gram Panchayat', and 'Gram Sabha'. The constitution of India defines Gram Sabha as "a body consisting of persons registered in the electoral rolls relating to village comprised within the area of Panchayat at the village level". It seems that the Gram Sabha mechanism is similar to Citizen Community Boards, with the difference that the funds reserved for CCB projects by the local government are not allocated to Gram Sabhas.

The administration of each district is further divided into offices and sub-offices managed by Executive District Officers (EDO) and District Officers (DO), respectively. The DCO is responsible for coordinating the activities of the EDO and DO at the district and tehsil levels (See Table 1).

The tehsil, also known as the Tehsil Municipal Administration (TMA), administers activities at the tehsil level. The TMA is a corporate body headed by the Tehsil Nazim. The Tehsil Municipal Officer (TMO), who reports directly to the Tehsil Nazim, is responsible for coordinating planning, infrastructure, municipal regulations and financial activities at the tehsil level through Town officers. The union council is composed of the union administration, including the elected Union Nazim and Naib Nazim as well as three secretaries. The major responsibility of the secretaries is to coordinate the functioning of union committees, municipal functions and community development activities under the administration of the Union Nazim (NRB, 2000, 2001; Paul, 2010).

\section{Evaluating Community Empowerment Mechanisms in Rural Development}

The decentralization reforms in Pakistan initiated different mechanisms to improve community empowerment and representation involving the mobilization of community resources, the development of community capacity, access to information, citizen participation, local elections, improved accountability mechanisms, poverty reduction strategies and the creation of tehsils and unions for proactive citizens. The creation of CCBs is one of the initiatives resulting from the decentralization reforms. The main goal of these boards is to improve the sense of community and ownership in communities by encouraging citizens to be proactive. To promote these community groups, the government reserved $25 \%$ of district budgets exclusively for the projects of CCBs. Local government ordinances provided a formal mechanism for every non-elected citizen to participate in and contribute to local development processes through CCBs. The creation of CCBs is formalized through registration with the Community Development Officer of the respective district. Under 


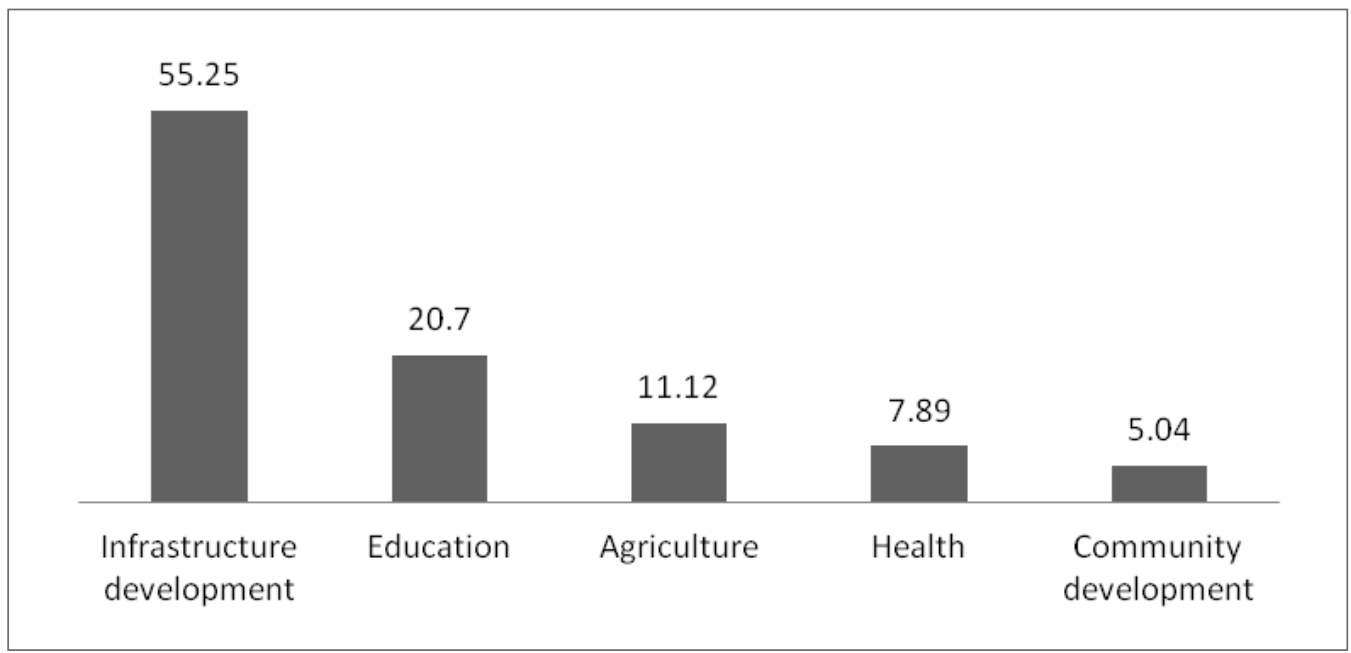

Figure 3. Percentage of types of projects undertaken by communities (DTCE, 2010)

the guidelines provided to CCBs, communities are responsible for the identification, planning, implementation and monitoring of all operations of the approved projects. Creating a supportive environment for communities to solve their own problems with financial support from the local government is an ideal approach to achieve community empowerment and sustainable development (Kurosaki, 2005). The following section evaluates the innovation related to community empowerment to ascertain how communities have shaped the socioeconomic and political capabilities of local governments in Pakistan with respect to rural development.

\section{Community Empowerment and Mobilization}

Local Government Ordinance 2001 mandated local governments in Pakistan to formulate mechanisms that foster citizen involvement in local development in terms of articulating their needs and participating in local development programs that foster a proactive citizenry and local development. District administrations and the Devolution Trust for Community Empowerment (DTCE) played a vital role in building capacity, mobilizing local communities to contribute 20 percent of project funds and making substantial efforts to solve local nuisances in the spirit of 'self-initiative' through CCBs. The enthusiasm for community participation is apparent in the growing number of CCBs in all of Pakistan's provinces. The total number of registered CCBs in 38 districts is 27,638; nearly 1910 CCBs have a female membership of at least 33 percent; there has been a total fund disbursement of 39.39 million GBP; and 13,899 projects had been undertaken as of December 2010. The projects undertaken by CCBs are divided into the following major sectors: infrastructure development, education, agriculture, health and community development (DTCE, 2010). Most CCBs have undertaken infrastructure development projects (see Figure 3).

With the help of the three tiers of local government, DTCE played a supportive role in community capacity building, including local membership, community mobilization programs, training programs for local elected representatives and the community, and technical support. Trained female elected councilors and community members are providing technical support to socially excluded groups. Approximately 2114 mobilization training programs were arranged for local elected representatives; 52,767 training programs were organized for union secretaries, citizens and district officials; and other technical support programs were arranged to raise community awareness. During projects, communities use their vast and inexpensive supply of labor, materials, local knowledge and land to build roads, infrastructure, community welfare centers 
and primary hygiene health care programs. Furthermore, improvements in community planning capacity and citizen participation through the local government system is promoting a great sense of ownership among community-implemented projects and has enhanced the communities' planning, budgeting and project management skills (Bardhan, 2002; Hayami \& Godo, 2005; Mansuri \& Rao, 2003). However, the challenge lies in how these efforts can be translated into sustainable enhanced access to resources and services for marginalized groups.

\section{Social Issues and Community Empowerment}

The elements that continued to hinder the potential of citizens and communities to foster local development are essentially related to the weak socioeconomic local government structure, especially in rural areas. The first important considerations for rural populations are low literacy rates, low levels of awareness, minimal access to reliable information, poor agricultural practices, poor shipping mechanisms, poor technical support, few processing facilities, poor market access, alimentary farming, poor access to digital media and slow expansion of commercialized agriculture, which collectively lead to low household incomes. Second, community members engaged in community development projects face numerous challenges. Community access to development information is low (only government workers and members have information regarding the availability of development funds), and there is little support from union offices (employees lack information regarding CCB registration and funding mechanisms). Third, most of the population lives in rural areas, and CCB registration information is only available at the district level. People who are already struggling to survive do not have time to visit district offices to obtain minute details; this problem is even more pronounced for women (Cheema \& Mohmand, 2007; Paul, 2010).

\section{Financial Contribution}

Another important factor impeding community empowerment in rural areas is financial contribution. Rural communities in this agricultural nation are entrenched in poverty. Contributing $20 \%$ of project costs is a difficult task for rural communities that are already barely surviving and combating the challenges of nature (earthquakes, floods) to feed their families. The government claims that this $20 \%$ contribution improves the sense of community, although for most of the communities, it is the major reason underlying low participation. Furthermore, the social fabric in Pakistan is very complex. The marginalization of local communities is a delicate issue that can complicate community empowerment. The population is divided according to complex social hierarchies, religious sects, ethnicity and gender. The greatest obstacles to local planning, community empowerment and the sustainability of community-driven projects involve the persistent central government control over district, tehsil and union councils, the elites' influence over CCBs, political interference, lack of community access to appropriate information, lack of information provision channels and lack of sufficient knowledge and skills among the three tiers of local government (Cheema \& Mohmand, 2007; Kurosaki, 2006; Paul, 2010).

\section{Elite Capture of CCBs}

Regarding the elites' influence over CCBs, local government employees-including councilors, Nazims, and other staff-often pursue their private interests by allocating CCB budgets and awarding CCB contracts to the detriment of the greater public good. Privileged citizens, including landowners and business people, often sponsor election candidates who subsequently help them to capture CCB funds after winning the election. Duncana and Goodwina (2008) argued that when elite-supported local representatives gain control, the broader community is likely to be poorly served because the elite tend to influence the government in pursuit of their own material interests. Such elite control becomes a source of serious problems in terms of equity, responsiveness and corruption. These members of the elite could instead assist local governments to obtain resources, information and greater authority.

\section{Accountability Mechanisms}

The decentralization of governance is a direct mechanism that ensures that elected representatives are held accountable to communities through bottom-up accountability (Blair, 2000). The accountability principle enforces the liability and responsibility of public authorities to provide satisfactory explanations to the 

Alsop, R., \& Heinsohn, N. (2005). Measuring Empowerment in Practice: Structuring Analysis and Framing Indicators (Policy Research Working Paper No. 3510), World Bank. Retrieved from http://siteresources.worldbank.org/INTEMPOWERMENT/ Resources/41307_wps3510.pdf

Andersson, K. P., Gibson, C. C., \& Lehoucq, F. (2004). The politics of decentralized natural resource governance. Political Science and Politics, 37(3), 421-426.

Andrews, C. W., \& de Vries, M. S. (2007). High expectations, varying outcomes: decentralization and participation in Brazil, Japan, Russia and Sweden. International Review of Administrative Sciences, 73(3), 424-451.

Anjum, Z. (2001). New Local Government System: A Step towards Community Empowerment. Pakistan Development Review, 40(4), 845-867.

Bardhan, P. (2002). Decentralization of Governance and Development Decentralization of Governance and Development. Journal of Economic Perspectives, 16(4), 185-205.

Blair, H. (2000). Participation and Accountability at the Periphery: Democratic Local Governance in Six Countries. World Development, 28(1), 21-39.

Bowles, S., \& Gintis, H. (2002). Social Capital And Community Governance. The Economic Journal, 112(483), F419-F436.

Buss, T. F., Marcela, T., \& Redburn, F. S. (2011). Economic Development, Citizen Participation. In Encyclopedia of Public Administration and Public Policy, Second Edition (pp. 569-576). London, UK: Taylor \& Francis.

Campbell, A., Hughes, J., Hewstone, M., \& Cairns, E. (2010). Social capital as a mechanism for building a sustainable society in Northern Ireland. Community Development Journal, 45(1), 22-38.

Cheema, A., \& Mohmand, S. (2007). Decentralisation and Inequality in Pakistan: Bridging the Gap that Divides?. In M. A. Saqib (Ed.), Devolution and Governance: Reforms in Pakistan (pp. 167-178). Karachi: Oxford University Press.

Corbett, J., \& Keller, P. (2004). Empowerment and participatory geographic information and multimedia systems: observations from two communities in Indonesia. Information Technologies and International Development, 2(2), 25-44.
Dale, A., \& Newman, L. (2010). Social capital: a necessary and sufficient condition for sustainable community development? Community Development Journal, 45(1), 5-21.

DTCE (2010). DTCE Monthly Progress Report - As on 30th September 2010. Islamabad: Devolution trust of Community Empowerment.

Dongier, P., Domelen, J. V., Ostrom, E., Ryan, A., Wakeman, W., Bebbington, A., Alkire, S., Esmail, T., Polski, M. (2003). Community Driven Development In J. Klugman (Ed.), A Sourcebook for Poverty Reduction Strategies Vol. 1: Core Techniques and Cross-Cutting Issues (pp. 301-331). Washington, DC: World Bank.

Duncana, S., \& Goodwina, M. (2008). Local economic policies: Local regeneration or political mobilization. Local Government Studies, 11(6), 75-96.

Fox, W., \& Meyer, I. H. (1995). Public Administration Dictionary. Cape Town: Juta.

Fraser, H. (2005). Four Different Approaches to Community Participation. Community Development Journal, 40(3), 286-300.

George, M. G., \& Costel, D. T. (2011). Capital Programming and Budgeting: Comparative Local Government Perspectives Encyclopedia of Public Administration and Public Policy, Second Edition (pp. 270-278), London, UK: Taylor \& Francis.

Gutberlet, J. (2009). Solidarity economy and recycling co-ops: micro-credit to alleviate poverty. Development in Practice, 19(6), 737-751.

Hankla, C., \& Downs, W. (2010). Decentralisation, Governance and the Structure of Local Political Institutions: Lessons for Reform? Local Government Studies, 36(6), 759-783.

Hayami, Y., \& Godo, Y. (2005). Development Economics: From the Poverty to the Wealth of Nations. Agosto: Oxford University Press.

Hjorth, P. (2003). Knowledge development and management for urban poverty alleviation. Habitat International, 27(3), 381-392.

Kakumba, U. (2010). Local government citizen participation and rural development: reflections on Uganda's decentralization system. International Review of Administrative Sciences, 76(1), 171-186.

Khwaja, A. I. (2004). "Is Increasing Community Participation Always a Good Thing?". Journal of the European Economic Association, 2(2-3), 427-436. 
Kurosaki, T. (2005). Determinants of Collective Action under Devolution Initiatives: The Case of Citizen Community Boards in Pakistan. Pakistan Development Review, 44(3), 253-270.

Kurosaki, T. (2006). Community and Economic Development in Pakistan: The Case of Citizen Community Boards in Hafizabad and a Japanese Perspectives. The Pakistan Development Review, 45(4), 575-585.

Laverack, G. (2001). An identification and interpretation of the organizational aspects of community empowerment. Community Development Journal, 36(2), 134-145.

Laverack, G. (2006). Using a 'domains' approach to build community empowerment. Community Development Journal, 41(1), 4-12.

Mansuri, G., \& Rao, V. (2003). Evaluating CommunityBased and Community-Driven Development: A Critical Review of the Evidence (Policy Research Working Paper No. 3209), World Bank. Retrieved from http:// siteresources.worldbank.org/INTECAREGTOPCOMDRIDEV/Resources/DECstudy.pdf

Michels, A., \& De Graaf, L. (2010). Examining Citizen Participation: Local Participatory Policy Making and Democracy. Local Government Studies, 36(4), 477-491.

Narayan, D., \& Petesch, P. (2002). Voices of the Poor: From Many Lands. New York, NY: Oxford University Press.

National Reconstruction Bureau (2000). The Local Government Plan 2000. Retrieved from http://www. nrb.gov.pk/publications/LG_Final_Plan_2000.pdf

National Reconstruction Bureau (2001). The Local Government System 2001. Retrieved from http:// www.nrb.gov.pk/local_government/default.asp

Patrick, W. O., \& Scott, F. (2011). Decentralization in Developing Countries In Encyclopedia of Public Administration and Public Policy, Second Edition (pp. 498-503). London, UK: Taylor \& Francis.

Paul, O. (2010). Pakistan: Devolution and Community Empowerment. South Asian Journal, 65-84.

Power, G., Khatun, S., \& Debeljak, K. (2011). Citizen Access to Information: Capturing the Evidence across Zambia, Ghana and Kenya: Handbook of Global Media Research. London: Wiley Blackwell.

Roche, B. (2010). New directions in Community-based Research. Toronto, ON: Wellesley Institute.

Rondinelli, D. (2006). Decentralization and Development'. In A. S. Haque \& H. Zafarullah (Eds.), Inter- national Development Governance (pp. 395- 417). London, UK: Taylor and Francis

Rondinelli, D. A. (1980). Government Decentralization in Comparative Perspective: Theory and Practice in Developing Countries. International Review of Administrative Sciences, 47, 133-145.

Saegaert, S. (2006). Building civic capacity in urban neighborhoods: an empirically grounded anatomy. Journal of Urban Affairs, 28(3), 275-294.

Salmon, A. (2007). Walking the talk: how participatory interview methods can democratize research. Qualitative Health Research, 17(7), 982-993.

Schulz, A., Israel, B. A., \& Zimmerman, M. A. Checkoway, B. N. (1995). Empowerment as a multi-level construct: perceived control at the individual, organizational and community levels. Health Education Research, 10(3), 309-327.

Sidorenko, A. (2006). Empowerment \& participation in policy action on ageing. UN Program on Ageing. Unpublished paper presented at the The International Design for All Conference 2006, Rovaniemi, Finland.

Speer, P. W., Jackson, C. B., \& Peterson, N. A. (2001). The relationship between social cohesion and empowerment: support and new implications for theory. Health Education and Behavior, 28(6), 716-732.

Wallerstein, N. (2006, February 11). What is the Evidence on Effectiveness of Empowerment to Improve Health?. Copenhagen: WHO Regional Office for Europe. Retrieved from http://www.euro. who.int/Document/E88086.pdf

Zimmerman, M. A. (2000). Empowerment theory: psychological, organizational, and community levels of analysis, In J. Rappaport and E. Seidman, (Eds.), Handbook of Community Psychology (pp. 43-63). New York, NY: Plenum Press.

\section{Endnotes}

1 CCB: A Citizen Community Board (CCB) is a voluntary organization based on the community in which people live. According to local government ordinance local people form a CCB with a chairman, a secretary, and general members. A registered CCB proposes development projects and contributes up to $20 \%$ of the total project cost. The local government funds $80 \%$ of the total project cost. 
